\title{
Conservation of Britain's biodiversity: distribution and status of the Welsh endemic Hieracium apheles, Hepste hawkweed (Asteraceae)
}

\author{
Timothy C.G. Rich \\ Cardiff, U.K.
}

Corresponding author: tim rich@sky.com

This pdf constitutes the Version of Record published $16^{\text {th }}$ September 2021

\begin{abstract}
The conservation status of Hieracium apheles P.D. Sell (Asteraceae), Hepste hawkweed, has been assessed. A lectotype for the basionym $H$. septentrionale Arv.-Touv. var. simplex Ley has been designated. It is a rare endemic restricted to the Hepste Glen in the Brecon Beacons (v.c.42), Wales. Only one population of five plants is known. It is assessed as 'Critically Endangered' under IUCN (2001) threat criteria.
\end{abstract}

Keywords: Critically Endangered; IUCN threat status; lectotype; Wales

\section{Introduction}

Hieracium apheles P.D. Sell (Asteraceae), Hepste hawkweed, is a rare UK endemic restricted to the Brecon Beacons in Wales (Sell \& Murrell, 2006; McCosh \& Rich, 2018; Rich, 2020). Rich $(2010,2011)$ reviewed information about it for Natural Resources Wales and further field work has been done up to 2013. The aim of this paper is to summarise what is known about it to enable a conservation plan to be drawn up and implemented.

Hieracium apheles was first described as a distinct species in Sell \& Murrell (2006), though it has had a long history during which it has been allied with several other species. It was first collected by A. Ley from the Hepste Glen in 1890. Ley (1895a) named it as $H$. diaphanum var. cacuminum Ley, but cultivated specimens were shortly afterwards distributed through the Botanical Exchange Club in 1894 as H. diaphanum var. stenolepis (Ley, 1895b), with comments from the Swedish expert Elfstrand that it was a variety of $H$. diaphanum Fr., and from the English expert F.J. Hanbury who thought that it was close to H. euprepes F.J. Hanbury. In 1904 more plants were distributed through the Botanical Exchange Club as H. scoticum F.J. Hanbury on the authority of W.R. Linton (Ley, 1905), and the Linton brothers distributed 1897 specimens with their Set of British hawkweeds (1896 etc.) as no. 166 H. scoticum. Further material was distributed in 1907 (with the locality again cited as the Mellte Glen) with a comment that the name $H$. scoticum remained doubtful, and that W.R. Linton "does not favour the suggestion that it can be placed under H. sparsifolium" (Ley, 1908). In 1907, W.R. Linton suggested it should be placed under H. septentrionale Arv.-Touv., and in 1909 Ley named it H. septentrionale Arv.-Touv. var. simplex (Ley, 1909). Pugsley (1948) disagreed with the suggestions it should be under $\mathrm{H}$. septentrionale and included it back under $\mathrm{H}$. scoticum with the comment it was a distinct form worthy of further investigation. Finally, it was named as a distinct species H. apheles by P.D. Sell (Sell \& Murrell, 2006). 
The basionym for $H$. apheles is $H$. septentrionale Arv.-Touv. var. simplex Ley (Ley 1909, page 50; Sell \& Murrell, 2006); a lectotype has been selected for the basionym and is hereby designated as the sheet in herb. F.J. Hanbury labelled "Rocks in and by the Hepste River near Penderyn, 30 July 1890, collected by the Rev, Augustin Ley" (BM; accession barcode number BM001187536); it should be noted that Ley (1909) cited the locality as Mellte Glen, but all specimens are from the Hepste Glen and this is thought to be a simple confusion.

\section{Morphology}

Hieracium apheles is a relatively distinct species of Hieracium section Oreadea (Fr.) Dahlst. characterised by the $2-5(-7)$, lanceolate to elliptical stems leaves with large teeth and cuneate bases, the few-flowered inflorescences with 2-9 capitula on long peduncles, the involucral bracts with numerous stellate and simple hairs but few glandular hairs, and the yellow styles (Figs. 1 and 2). Other species in the Hepste Glen/Mellte Glen area with which it could be confused are $H$. charitodon and $H$. nidense in section Tridentata; both these species have more stem leaves with larger teeth.

Following rediscovery of the population in the Hepste Glen (see below), the description by Sell \& Murrell (2006) has been revised as it was based on only a limited sample of cultivated plants in CGE. The major difference was that Sell \& Murrell (2006) described $H$. apheles in both the text and key as having numerous stellate hairs on the involucral bracts, whereas the wild plants and other herbarium material had virtually no stellate hairs except on the lowest outer bracts. A revised description is as follows:

Perennial herb to $60 \mathrm{~cm}(-100 \mathrm{~cm})$ tall, yellowish-green to dark green. Basal rosette leaves present at flowering. Petioles to $3 \mathrm{~cm}$ with long simple hairs. Lamina to $8 \times 3.5 \mathrm{~cm}$, elliptic, base cuneate to attenuate, apex acute, obtuse or mucronulate, margins remotely denticulate with small teeth, with numerous simple hairs above and more numerous simple hairs beneath, with a few stellate hairs and numerous simple hairs along the margins, weakly flecked purple beneath. Stem erect, purple-flushed at base with dense, long, spreading simple white hairs to $4 \mathrm{~mm}$ long, and with sparse simple white hairs with red bases above and numerous stellate hairs, glandular hairs absent. Stem leaves up to 7 , the lower petiolate below and the upper sessile, gradually decreasing in size, the lower leaves 9-10 x 2-3.5 cm elliptic-lanceolate to lanceolate, base cuneate to attenuate, apex acute, margins with a few large, sharp forward pointing teeth, with simple hairs \pm absent or sparse near margins above and frequent below, with sparse stellate hairs below and on margins. Upper stem leaves smaller to $2.5-5 \times 0.5-1.5 \mathrm{~cm}$ lanceolate to linear-lanceolate, sessile, apex acute to acuminate, \pm glabrous above and with sparse simple hairs below, and sparse stellate hairs on margins and below. Inflorescence furcated-corymbose, capitula 2-9, peduncles long 6-11 cm with dense stellate hairs and sparse simple hairs. Capitula $30-40 \mathrm{~mm}$ across, rounded at base. Involucral bracts to $12 \mathrm{~mm}(-14 \mathrm{~mm}$ in fruit) x 1.5-1.8 mm (innermost $0.8 \mathrm{~mm}$ ), linear-lanceolate, obtuse at apex, simple eglandular hairs numerous, black-based with white tips, stellate hairs very few at base on middle or inner bracts or frequent on margins of shorter outer bracts, glandular hairs small and sparse at very base of involucre, or inconspicuous. Some bracts with stellate hairs at tip. Ligules yellow, glabrous at tips in bud. Styles yellow. 


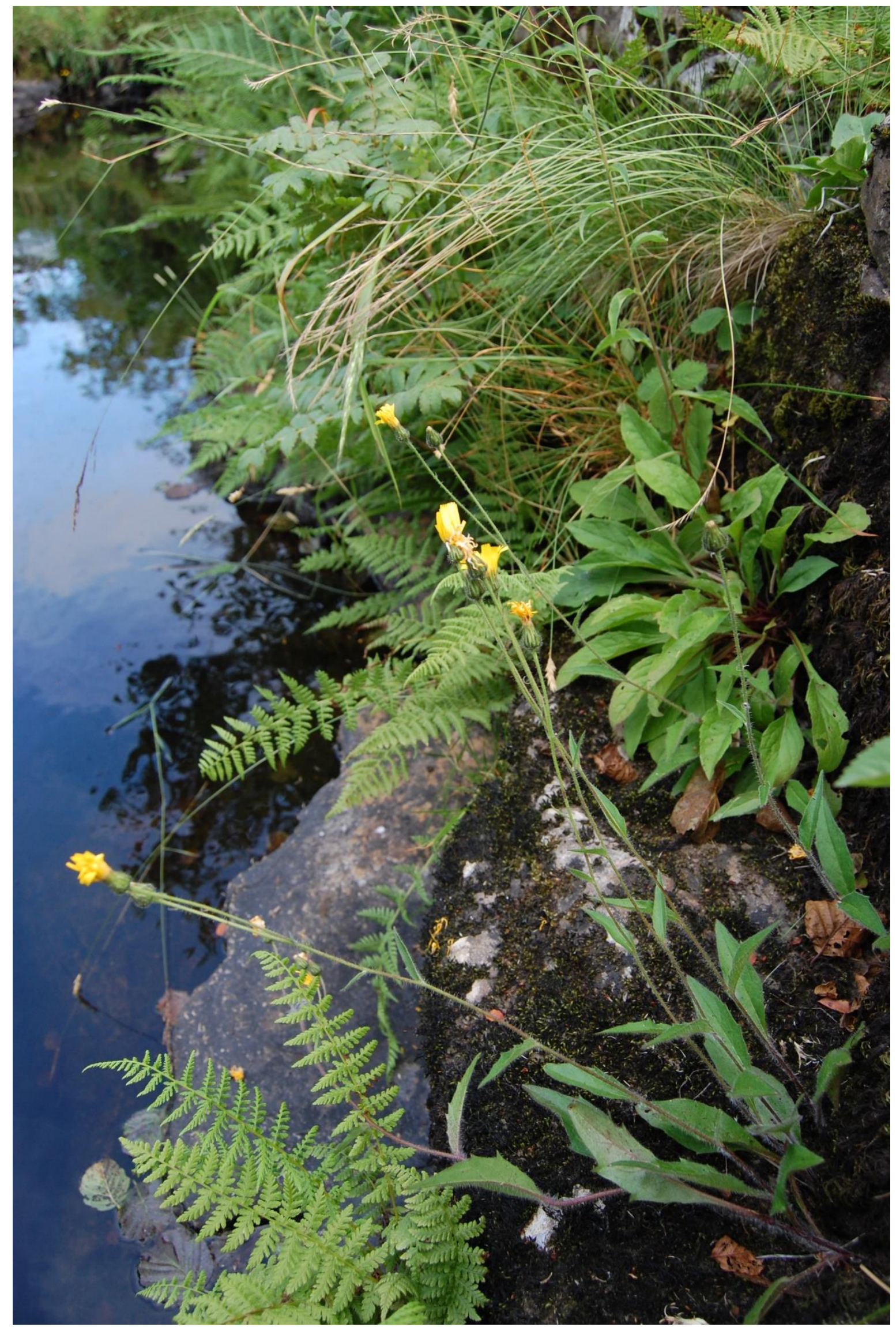

Figure 1. Hieracium apheles. 


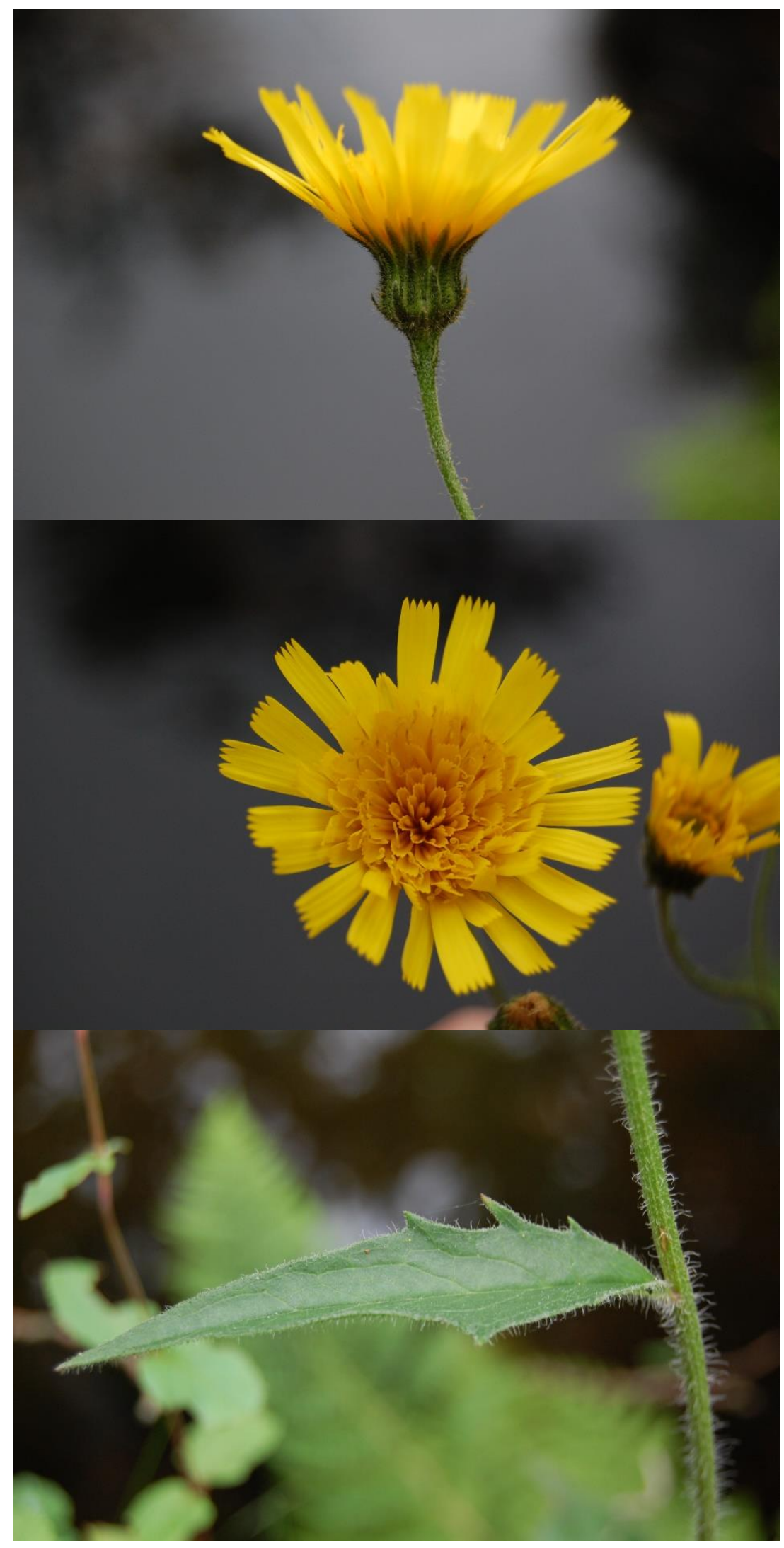

Figure 2. Upper stem leaf and capitulum of Hieracium apheles. 


\section{Distribution and population size}

Historical records were compiled from herbaria (BM, CGE, NMW), literature and the Hieracium database maintained by D. J. McCosh (October 2020 version); the records are summarised in Appendix 1. The historical records indicate it has been recorded with certainty only from the Hepste Glen in v.c.42, Brecon (Fig. 3).

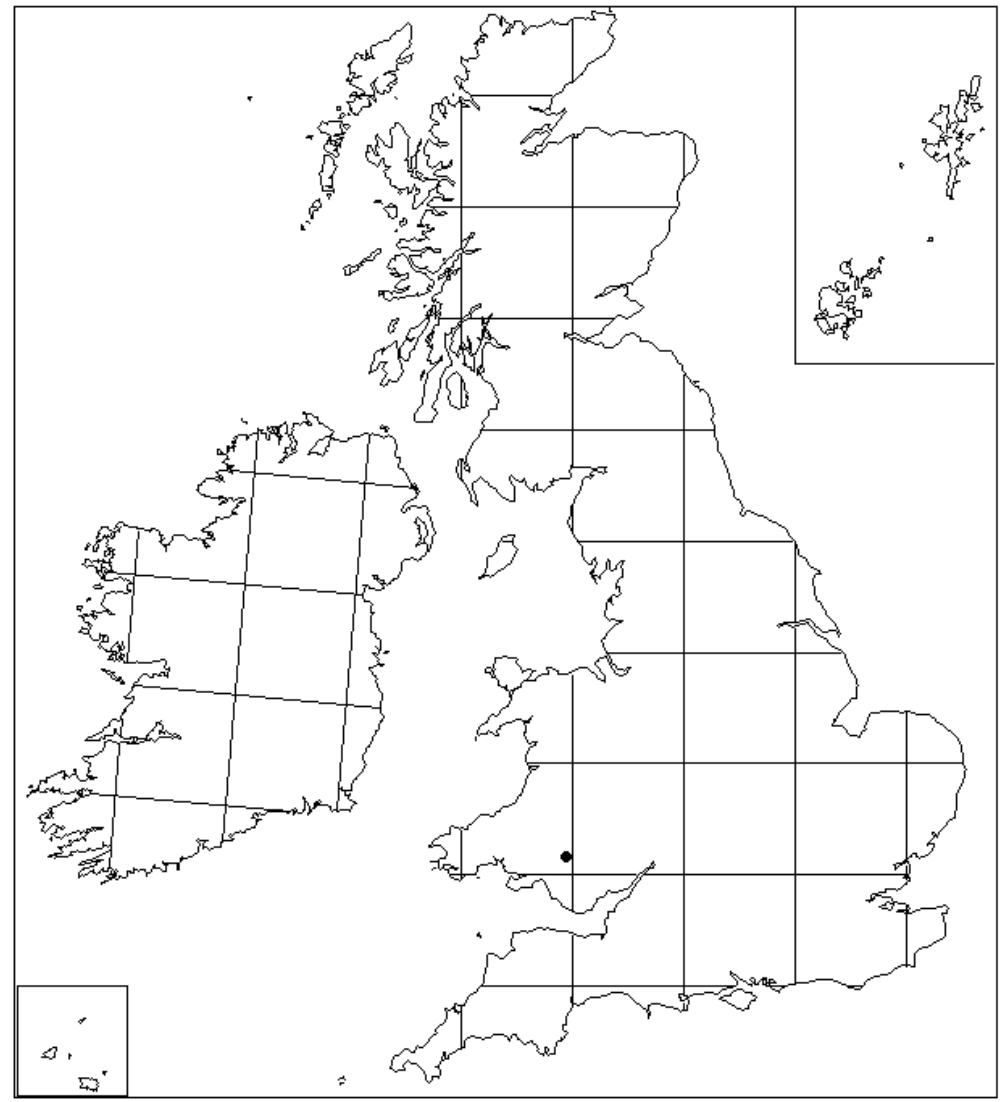

Figure 3. Distribution map of Hieracium apheles.

The Hepste Glen was searched on 13 July 2010 from Sgwd yr Eira SN928100 to Bryn-cul SN940105 (Rich \& Thomas, 2010). Below Sgwd yr Eira, the Afon Hepste is quite shaded in tall woodland. Between Sgwd yr Eira and Caerhowell, the Afon Hepste was relatively shaded and had mainly acidic rock, and very few hawkweeds were seen. Above Caerhowell, the banks were more open with rocks and a series of small waterfalls had $H$. argillaceum, $H$. sabaudum, $H$. strigosum and $H$. subcrocatum. Five plants of $H$. apheles were found on low rocks by a pool below a small waterfall and gorge at SN941101. This site is probably further north than Ley's 'rock in the Hepste Glen at the point nearest to Penderyn'. Above Bryn-cul, the Afon Hepste runs through farmland, is densely shaded with trees and is unsuitable.

\section{Life cycle and Ecology}

Hieracium apheles is a perennial which is probably quite long-lived and the five wild plants were seen for at least four years 2010-2013. It is probably a polyploid apomict like most other British Hieracium species; Sell \& Murrell (2006) stated it is apomictic but this was not actually tested. The main flowering period is from June to July. Most seed is ripe by August, the seeds have a small pappus and are wind-dispersed or perhaps washed along the Afon Hepste. 


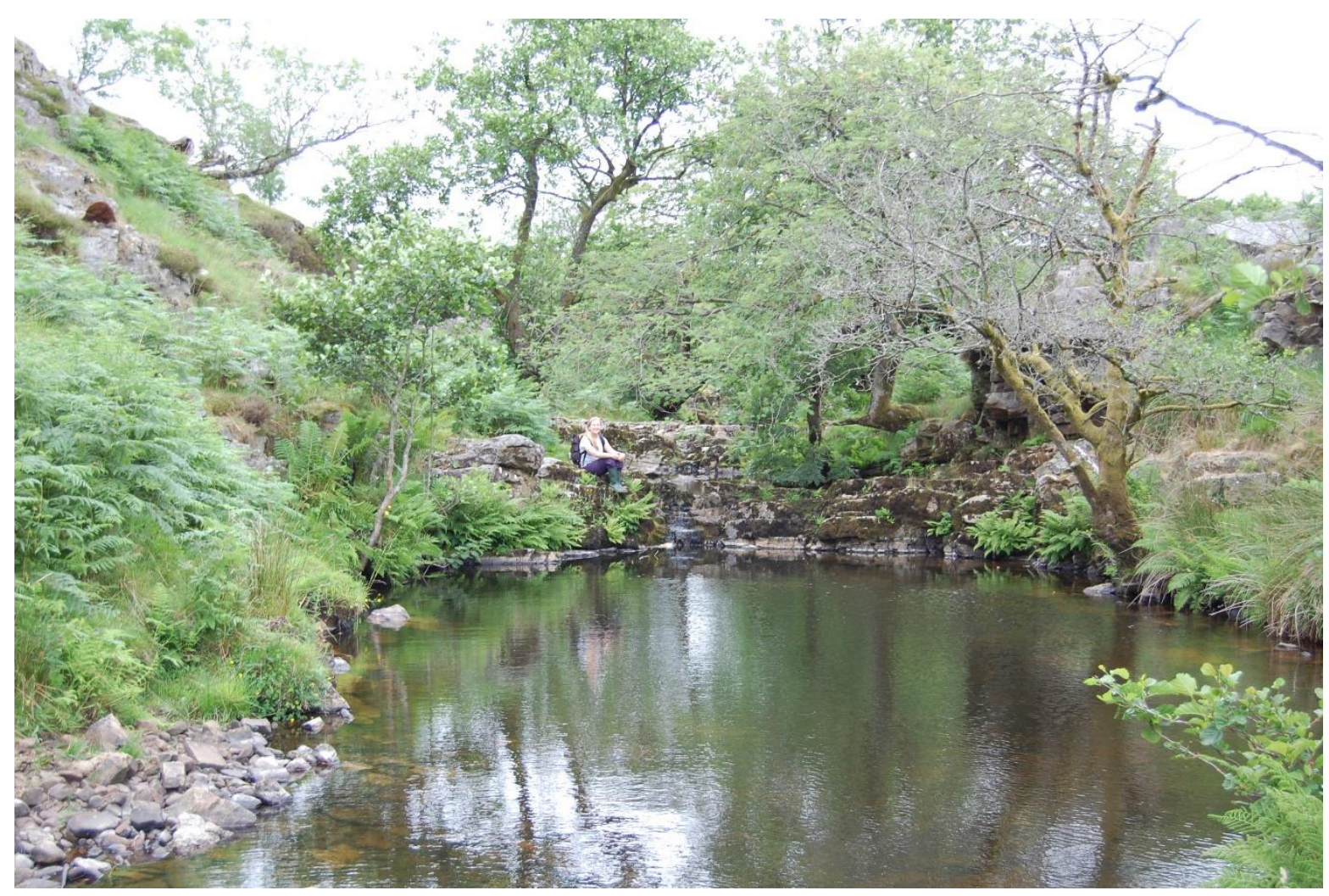

Figure 4. Habitat of Hieracium apheles.

The $H$. apheles plants were rooted in clefts in the Twrch Sandstone Formation rocks which are interbedded sandstones and conglomerates of Carboniferous age (Fig. 4). The plants were about $0.5 \mathrm{~m}$ above the summer water levels, but were within the flood zone which is probably important to maintain relatively open conditions, however in August 2010 a flash flood washed away all seed from the plants. It is associated with Anthoxanthum odoratum (occasional), Athyrium filix-femina (rare to abundant), Dryopteris dilatata (rare), Geranium robertianum (rare), Geum urbanum (rare), Hieracium cf. subcrocatum (rare), Hieracium sabaudum (rare), Luzula campestris (rare), Nardus stricta (rare), Poa trivialis (rare), Potentilla sterilis (rare), Schedonorus gigantea (rare), Solidago virgaurea (occasional), Sorbus aucuparia (one small shrub) and Succisa pratensis (rare). The altitude is $250 \mathrm{~m}$.

In 2010 the plants were located out of the reach of sheep, as like, most hawkweeds, they are susceptible to grazing. In 2013 the river was fenced on the east side and was only lightly grazed by sheep thereafter. Plants were still present on 24 May 2021, and a population count on 18 August by Andy Shaw indicated five plants were still present, two of which were vegetative.

\section{Discussion}

Hieracium apheles is assessed as 'Critically Endangered' under IUCN (2001) threat criteria based on the occurrence of five plants in one locality. The site has no protection or designation. There is no indication of the population size during Ley's time, but it is now extremely vulnerable. A small collection of seeds from two plants was deposited in the Millennium Seed Bank in 2013 and population reinforcement programme was begun in 2021 by Andy Shaw. 


\section{Acknowledgements}

I thank the Keepers of herbaria for access to material and libraries, John Hunnex for help with the lectotype, David McCosh for checking the identification of plants and for information from the Hieracium database, Seren Thomas and for help with field work, Ceri Gait for growing plants and Andy Shaw for undertaking the restocking programme.

\section{References}

IUCN 2001. IUCN Red list categories and criteria. Version 3.1. Gland: International Union for Conservation of Nature.

Ley, A. 1895a. H. diaphanum Fr. var. cacuminum, n. var. Journal of Botany 33: 86-87.

Ley, A. 1895b. H. diaphanum, Fr., var. stenolepis, Lindeb. Botanical Exchange Club Report for 1894: 455-456.

Ley, A. 1905. H. scoticum, F.J. Hanb. Botanical Society and Exchange Club Report for 1905: 28.

Ley, A. 1908. H. - ?. Botanical Society and Exchange Club Report for 1907: 300.

Ley, A. 1909. Brecon and West Yorkshire hawkweeds. Journal of Botany 47: 8-16 and 4755.

McCosh, D.J. \& Rich, T.C.G. 2018. Atlas of British and Irish Hawkweeds (Pilosella Hill and Hieracium L.). $2^{\text {nd }}$ ed. Harpenden: Botanical Society of Britain and Ireland.

Pugsley, H.W. 1948. A Prodromus of the British Hieracia. Journal of the Linnean Society of London (Botany) 54: 1-356.

Rich, T.C.G. 2010. Conservation of critical taxa in Wales 1: Threatened Hawkweeds (Hieracium) species. CCW Science Report No: 931, 51 pp. Bangor: Countryside Council for Wales.

Rich, T.C.G. 2011. Conservation of critical taxa in Wales: additional information. CCW Science Report No: 990, 28 pp. Bangor: Countryside Council for Wales.

Rich, T.C.G. 2020. List of vascular plants endemic to Britain, Ireland and the Channel Islands 2020. British \& Irish Botany 2: 169-189.

Rich, T.C.G. \& Thomas, S. 2010. Hieracium apheles Hepste Hawkweed survey 2010. Unpublished report, National Museum of Wales.

Sell, P.[D.] \& Murrell, G. 2006. Flora of Great Britain and Ireland, volume 4. Cambridge: Cambridge University Press.

Copyright retained by author(s). Published by BSBI under the terms of the Creative Commons Attribution 4.0 International Public License.

ISSN: $2632-4970$

https://doi.org/10.33928/bib.2021.03.289 


\section{Appendix 1. Summary of records of Hieracium apheles.}

Wild collected material:

Hepste Glen: 1890 (Ley 1909). Rocks in and by the Hepste River near Penderyn, 30 July 1890, A. Ley (lectotype; BM); rock in the Hepste glen (at the point nearest Penderyn), 27 June 1896, F.J. Hanbury \& A. Ley (CGE); 7 July 1896, F.J. Hanbury (BM); river bank, 9 July 1896, A. Ley \& W.A. Shoolbred (NMW); five plants, 13 July 2010, T.C.G. Rich \& S. Thomas (NMW). five plants, 5 September 2010, T.C.G. Rich; five plants, 2 June 2011, T.C.G. Rich, N. de Vere, C. Trinder \& C. Long. September 2012, T.C.G. Rich \& C. Gait. five plants, July 2013 and 24 August 2013 (seed collected from two plants on latter date), T.C.G. Rich.

Other records:

[A specimen listed in the McCosh database from Cwm Taf Fechan, 15 August 1894, W.A. Shoolbred has not been traced in BM and may have been redetermined.]

Mellte Glen: Literature records for Mellte Glen (Ley, 1908, 1909) are presumably a result of confusion of the adjacent valleys as all the herbarium material is from the Hepste Glen.

Cultivated material: H. diaphanum var. stenolepis, root from the Hepste [Kepste] Glen, 17 June 1894, A. Ley (BM, NMW; Ley, 1895b). H. diaphanum var. stenolepis, origin Breconshire 11 June 1896, A. Ley (BM, CGE; Ley, 1909). H. scoticum F.J. Hanbury, Set No. 166, origin Hepste Glen, A. Ley, 19 June 1897, cultivated by E.F. \& W.R. Linton (BM, CGE, NMW). H. scoticum F. J. Hanbury forma, origin Hepste Glen, 23 June 1902, A. Ley (BM, CGE, NMW). H. scoticum F.J. Hanbury, origin Hepste Glen, 22 June 1904, A. Ley (CGE; Ley, 1909). H. scoticum F.J. Hanbury, origin ? [Penwyllt cited on transcribed label], 24 July 1906, A. Ley (BM). H. -?, origin Hepste Glen, 3 July 1907, A. Ley (BM, CGE). H. septentrionale Arv.-Touv. var. simplex - origin Hepste Glen, 12 June 1908, A. Ley (BM, NMW). 